\title{
A lupus nephritis kezelésének irányelvei, valamint a mycofenolat mofetil hatékonyságának bemutatása intézetünk lupus nephritises betegeinek körében
}

\author{
Szabó Melinda Zsuzsanna dr. - Kiss Emese dr. \\ Országos Reumatológiai és Fizioterápiás Intézet, Budapest
}

\begin{abstract}
A szerző́k közleményükben a lupus nephritis kezelésének legújabb irányelvei mellett bemutatják saját mycofenolat mofetillel szerzett tapasztalataikat a betegség kezelésében. A lupus nephritis és főleg a proliferatív formája olyan gyakori és komoly manifesztációja a szisztémás lupus erythematosusnak, amely végstádiumú veseelégtelenséghez vagy akár halálhoz is vezethet. Az elmúlt évtizedekben a lupus nephritis kezelése sokat fejlődött, ma már a kedvezőbb mellékhatás-profilú mycofenolat mofetil a cyclophosphamid alternatívájává vált a III-as és IV-es osztályú glomerulonephritis indukciós és fenntartó kezelésében. Lupus nephritis diagnózissal eddig 25 betegüknek kértek egyedi méltányosság alapján támogatást mycofenolat mofetil adására. Szövettanilag legtöbben a WHO III (A/C) és IV (A) szövettani osztályába tartoztak (30-30\%), beszúkült vesefunkció csak 16\%-ukban volt jelen. Glükokortikoid és cyclophosphamid indukciós kezelés után adott mycofenolatterápia mellett az átlagos napi proteinuria $3,18 \mathrm{~g} /$ napról $1,06 \mathrm{~g} /$ napra csökkent. A betegek $24 \%$-ánál jött létre komplett, 48\%-ánál részleges remisszió. Ezek alapján a mycofenolat mofetil hatékony kezelésnek tartható a proliferatív lupus nephritis kezelésében. Orv. Hetil., 2016, 157(35), $1385-1393$.
\end{abstract}

Kulcsszavak: lupus nephritis, szisztémás lupus erythematosus, mycofenolat mofetil, cyclophosphamid, rituximab

Clinical guideline for the treatment of lupus nephritis and single-centre results of mycofenolate mofetil among patients with lupus nephritis in the National Institute of Rheumatology and Physiotherapy, Budapest

The authors present the latest guideline for the treatment of lupus nephritis and their own single-centre results with mycofenolate mofetil treated lupus nephritis. Lupus nephritis and mainly its proliferative form is a frequent and potentially life-threatening manifestation of systemic lupus erythematosus that can lead to end-stage renal disease. The treatment of lupus nephritis greatly improved in the last decades; mycofenolate mofetil has become an alternative of cyclophosphamide both in remission induction and as a maintenance regimen as well in the treatment of Class III and IV glomerulonephritis. The authors ordered mycofenolate mofetil for 25 patients with lupus nephritis so far. Histologically most of them had Class III (A/C) or IV (A) glomerulonephritis (30-30\%), and only $16 \%$ of the patients had renal impairment at that time. Mycofenolate mofetil given after glucocorticoid and cyclophosphamide induction therapy reduced the daily proteinuria from 3.18 grs to 1.06 grs. Complete remission could be achieved in $24 \%$ and partial remission in $48 \%$ of the patients. The authors conclude that mycofenolate mofetil is effective in the therapy of lupus nephritis.

Keywords: lupus nephritis, systemic lupus erythematosus, mycofenolate mofetil, cyclophosphamide, rituximab

Szabó, M. Zs., Kiss, E. [Clinical guideline for the treatment of lupus nephritis and a single-centre results of mycofenolate mofetil among patients with lupus nephritis in the National Institute of Rheumatology and Physiotherapy, Budapest]. Orv. Hetil., 2016, 157(35), 1385-1393. 


\section{Rövidítések}

ACE = angiotenzinkonvertáló enzim; ALMS = Aspreva Lupus Management Study; $\mathrm{ARB}=$ angiotenzinreceptor-blokkoló; $\mathrm{AZA}=$ azathioprin; $\mathrm{BlyS}=\mathrm{B}$-lymphocyta-stimulátor; $\mathrm{CNI}=$ calcineurininhibitor; CsA = cyclosporin A; CTLA $4=$ (cytotoxic T-lymphocyte associated protein 4) citotoxikus T-lymphocyta-asszociált fehérje $4 ; \mathrm{CYC}=$ cyclophosphamid; DNS = dezoxiribonukleinsav; ESRD $=$ (end-stage renal disease) végstádiumú veseelégtelenség; GFR = glomerulusfiltrációs ráta; $\mathrm{HCQ}=$ hidroxikloroquin; HLA = humán leukocyta-antigén; ISN/RPS = (International Society of Nephrology/Renal Pathology Society) Nemzetközi Nefrológiai/Vesepatológiai Társaság; $\mathrm{LN}=$ lupus nephritis; $\mathrm{MHC}=$ (major histocompatibility complex) fó hisztokompatibilitási komplex; $\mathrm{MMF}=\mathrm{my}-$ cofenolat mofetil; MPA = mikofenolsav; $\mathrm{NIH}=($ National Institutes of Health) Nemzeti Egészségügyi Intézet; SLE = szisztémás lupus erythematosus; $\mathrm{WHO}=($ World Health Organization) Egészségügyi Világszervezet

\section{Epidemiológia}

A lupus nephritis ( $\mathrm{LN}$ ) a szisztémás lupus erythematosus (SLE) egyik gyakori és legsúlyosabb manifesztációja, amely a betegek 30-60\%-ában, általában a betegség első néhány évében alakul ki, de 25-50\%-ukban már az SLE diagnózisának felállításakor jelen van [1]. Az érintett betegek nagy része 50 év alatti nő. Ugyanakkor az SLE-s férfi betegekben gyakrabban alakul ki veseérintettség, és a prognózisuk is rosszabb [2]. A terápiás lehetőségek fejlődésével az LN 5 éves túlélése az elmúlt fél évszázadban 44\%-ról közel 96\%-ra nőtt [3]. SLE-s betegekben az egyik legrosszabb prognosztikai tényező a lupus nephritis kialakulása [4]. Az LN prognózisát nagyban meghatározza a vesebiopszia eredménye, az aktív gyulladás és a krónikus elváltozások aránya [5].

\section{Patogenezis}

A betegség pontos etiopatogenezise a mai napig nem ismert, de nagy valószínúséggel genetikai, hormonális és környezeti tényezők is szerepet játszanak a manifesztációk kialakulásában és a súlyosság fokában. A genetikai fogékonyságot támasztja alá, hogy magasabb az SLE incidenciája monozigóta ikrekben, valamint családi halmozódást is megfigyeltek [6]. A genetikai fogékonyság hátterében részben $\mathrm{MHC}$, részben nem $\mathrm{MHC}$ gének állnak, szerepüket SLE-s állatmodellekben, illetve humán megfigyelésekben igazolták. Számos gént hoztak összefüggésbe az SLE-vel, valamint a lupus nephritisszel, a prediszponáló locusok a HLA-DR2, HLA-DR3, HLADRB1, HLA-DRB*0301 és a HLA-DRBl *1501 [7]. A hormonális tényezők szerepére utal a női dominancia, valamint az, hogy pubertás előtt ritkán jelentkezik, terhesség alatt vagy post partum időszakban azonban gyakori a relapsus [8].

A betegség patogenezisére az immunreguláció komplex zavara jellemző. Az autotolerancia „áttörése” indítja el a folyamatot, az autoreaktív T- és B-sejtek aktiválódnak és perzisztálnak. A fokozott apoptózis, az apoptotikus törmeléket eltakarító mechanizmusok zavara, a DNS-metiláció zavara, illetve a DNS-repair károsodása révén megnő és folyamatossá válik az autoantigén-kínálat. Az aktivált autoreaktív B-sejtek patogén autoantitesteket termelnek, ezek egy része klasszikus immunkomplex-mechanizmussal, komplementet aktiválva fejti ki a hatását, másik része az antitestdependens citotoxicitás révén. A fokozott B-sejt-aktivitás döntően T-sejt-függő jelenség, befolyásolja a fokozott CD4+ T helper hatás és a csökkent regulatorikus CD4+/CD25+ T-sejt-aktivitás. Az immunkomplex-mediált folyamat során a patológiás immunkomplexek lerakódnak a különböző szövetekben, ahol humorális és celluláris tényezőket aktiválnak, ennek következtében gyulladásos mediátorok szabadulnak fel, komplementaktiváció, fibrindepozíció, mononukleáris sejtinfiltráció és aktiváció jön létre, amelyek együttesen a szövet károsodásához vezetnek. Újabb adatok alapján a Th1-, Th2- és Th17-sejtek patogenetikai szerepe is bizonyítottnak látszik az SLE etiopatogenezisében [9].

\section{A lupus nephritis osztályozása, lefolyása, prognózisa}

Lupus nephritises betegekben tehát az immunkomplexek lerakódása és a következményesen kialakult gyulladás vezet glomerulonephritishez. A glomeruluskárosodást három különböző mintázatba sorolhatjuk: mesangialis, endothelialis és epithelialis [10]. A többi glomerularis betegséghez hasonlóan az $\mathrm{LN}$ is több területet érinthet, hisztopatológialag pleiomorf lehet, amely nehezítheti a klinikai státusz értékelését és a glomeruluskárosodás mértékének megítélését.

A vesebiopszia a gold standard a diagnosztikában.

A vesebiopszia mindenképpen elvégzendö, ha:

- emelkedik a szérumkreatinin-érték (és nem szepszis, hypovolaemia vagy gyógyszerhatás okozza);

- a beteg 24 óra alatt egy grammnál több fehérjét ürít a vizeletében (24 órás gyưjtött vizeletból vagy protein/ kreatinin hányados alapján);

- 24 óra alatt 0,5 grammnál magasabb proteinura mellé haematuria társul (látóterenként $>5$ vörösvértest);

- 24 óra alatt 0,5 grammnál magasabb proteinuria mellett aktív vizeletüledék van jelen.

Az Egészségügyi Világszervezet (World Health Organization - WHO) és a Nemzetközi Nefrológiai/Vesepatológiai Társaság (International Society of Nephrology/ Renal Pathology Society - ISN/RPS) határozta meg a biopsziás mintában jelen levő glomerularis patológia alapján a lupus nephritis klasszifikációját (1. táblázat).

A lupus nephritis többnyire tünetmentesen vagy csak enyhe tünetekkel zajlik, ezért különösen fontos a betegek rendszeres szúrése a minél korábbi diagnózishoz. A klinikai és a laboratóriumi jelek már utalhatnak a vese szövettani elváltozására: a proteinuria, a mikroszkópos 
1. táblázat |A lupus nephritis osztályozása

\begin{tabular}{|c|c|c|c|c|c|}
\hline Osztály & & $\begin{array}{l}\text { Immunkomplexek } \\
\text { elhelyezkedése }\end{array}$ & Mikroszkóposan & ESRD & Kezelés \\
\hline$I$. & Minimális mesangialis & Mesangium & Nincs hypercellularitás & Ritka & $\begin{array}{l}\text { ACEI/ARB, } \\
\text { HCQ }\end{array}$ \\
\hline II. & Mesangialis proliferatio & Mesangium & Mesangialis hypercellularitás & Ritka & ACEI/ARB \\
\hline III. & Fokális & Subendothelium & $\begin{array}{l}\text { Endo-, illetve extrakapilláris } \\
\text { hypercellularitás, glomerulusok }>50 \% \text {-a } \\
\text { érintett }\end{array}$ & $10-20 \%$ & $\begin{array}{l}\text { ACEI/ARB, } \\
\text { HCQ }\end{array}$ \\
\hline III (A) & Aktív laesio & & & & \\
\hline III $(\mathrm{A} / \mathrm{C})$ & Aktív és krónikus laesio & & & & \\
\hline III $(\mathrm{C})$ & Krónikus laesio & & & & \\
\hline$I V$. & Diffúz & Subendothelium & $\begin{array}{l}\text { Endo-, illetve extrakapilláris } \\
\text { hypercellularitás, glomerulusok }>0 \% \text {-a } \\
\text { érintett }\end{array}$ & $25-40 \%$ & $\begin{array}{l}\text { ACEI/ARB, } \\
\text { GC és ISU }\end{array}$ \\
\hline IV-S vagy IV-G & $\begin{array}{l}\text { Szegmentális vagy } \\
\text { globális }\end{array}$ & & & & \\
\hline IV (A) & Aktív laesio & & & & \\
\hline $\mathrm{IV}(\mathrm{A} / \mathrm{C})$ & Aktív és krónikus laesio & & & & \\
\hline $\mathrm{IV}(\mathrm{C})$ & Krónikus laesio & & & & \\
\hline$V$. & Membranosus & Subepithelium & $\begin{array}{l}\text { Bazálmembrán megvastagodása; } \\
\text { III-assal és IV-essel együtt lehet jelen }\end{array}$ & $<10 \%$ & \\
\hline$V I$. & $\begin{array}{l}\text { Elörehaladott } \\
\text { szklerotizáló }\end{array}$ & Változó & $\begin{array}{l}\text { Glomerulusok >90\%-a globálisan } \\
\text { szklerotizált, nincs aktív gyulladás }\end{array}$ & Gyakran & \\
\hline
\end{tabular}

$\mathrm{A}=$ aktív; ACEI = angiotenzinkonvertálóenzim-inhibitor; $\mathrm{ARB}=$ angiotenzinreceptor-blokkoló; $\mathrm{C}$ = krónikus; ESRD = (end-stage renal disease $)$ végstádiumú veseelégtelenség; $\mathrm{GC}$ = glükokortikoid; $\mathrm{HCQ}=$ hidroxikloroquin; $\mathrm{ISU}=$ immunszuppresszív szer.

haematuria, aktív vizeletüledék, nehezen uralható hypertonia proliferatív lupus nephritisnél szokott elsősorban előfordulni és gyakran vezet veseelégtelenséghez. A perifériás oedemával, hypercoagulabilitással járó nephrosisszindróma inkább membranosus vagy proliferatív formákban alakul ki. Az LN ritkán kezdődik akut veseelégtelenséggel is, illetve a súlyos glomerularis gyulladás, félhold-képződés és fibrinoid nekrózis miatt lehet rapidan progresszív. A legtöbb betegben az LN szubakut vagy krónikus állapot, kezeléssel remisszió indukálható, ugyanakkor a spontán relapsusok aránya meglehetősen gyakori [11].

Külön kiemelendő az úgynevezett „silent” vagy „csendes" lupus nephritis, amikor a teljesen tünetmentes betegen elvégzett biopszia nephritist igazol [12]. Egy vizsgálatban SLE-s betegeknek ajánlották fel a biopsziás mintavétel lehetőségét, 55\%-uknak nem volt klinikailag vesebetegségre utaló tünete, ennek ellenére a klinikailag tünetmentes betegek 15\%-ánál III-as vagy IV-es, további 10\%-uknál V-ös stádiumú lupus nephritist diagnosztizáltak [13].

A mesangialis lupus nephritises betegeknek csak mérsékelt laboratóriumi eltérése van, ritkán alakul ki náluk végstádiumú veseelégtelenség (end-stage renal disease ESRD). A membranosus formában gyakran nephrosis a mortalitás oka, ugyanakkor a megfelelő kezeléssel 90\%-uknál remisszió érhető el, csak 10\%-uknál alakul ki ESRD a következő 15 évben [14]. A diffúz proliferatív formának rosszabb a prognózisa, mint a fokálisnak, itt a végállapotú veseelégtelenség 15 éven belüli kialakulásának valószínúsége 25-40\% [15]. Az előrehaladott szklerotizáló glomerulonephritisben a glomerulusok több mint 90\%-ában globális szklerózist mutattak ki, náluk a leggyakoribb az ESRD. További rossz prognosztikai tényező a későn megkezdett immunszuppresszív terápia, a terápiára adott részleges válasz, a több alkalommal relabáló nephritis, a nehezen kontrollálható hypertonia, renalis anaemia, emelkedett szérumkreatinin-szint, illetve a gyors GFR-csökkenés. Azoknál a betegeknél, akiknél a proliferatív forma a membranosushoz társul, 20-48\% a 10 éves túlélés valószínúsége, míg a csak membranosus LN-ben szenvedőké 72\% [16].

\section{A kezelés célja}

Nem minden lupus nephritises beteg szorul immunszuppresszív kezelésre, a terápia meghatározásában döntő a vesebiopszia eredménye. Az I-es és II-es osztályba tartozó betegeknél elég az optimális vesevédelem: hidroxikloroquin adása, valamint tenziókontroll és veseprotekció angiotenzinkonvertálóenzim- (ACE-) gátlóval és/vagy angiotenzinreceptor-blokkolóval (ARB). A III-as 
és IV-es osztályba tartozó proliferatív lupus nephritises betegek immunszuppresszív kezelését pedig minél hamarabb meg kell kezdeni. A tisztán V-ös típus általában kortikoszteroidra jól reagál, csak ritkán van szükség más immunszuppresszív terápiára. A globális szklerózisban pedig az immunszuppressziónak már nincs szerepe, szupportív terápia bevezetése szükséges.

A legfőbb célok a minél hamarabbi remisszió elérése, a fellángolások megelőzése, a vesekárosodás megelőzése, a maximális életminőség megőrzése és a kezelés mellékhatásainak minimalizálása. A jelenlegi gyakorlat szerint remisszióindukcióra egy potenciálisan toxikusabb gyógyszert használunk rövidebb ideig, majd hosszabb távon kevésbé toxikus fenntartó kezelésre térünk át. A korai válasz elmaradása rossz prognosztikai jel [17].

\section{ISN I. és II. osztályú lupus nephritis kezelése}

Az I-es és II-es szövettani típusú betegségnek nagyon jó a prognózisa. A kezelési stratégia a beteg folyamatos követése, tenziókontrollja. Ha a proteinuria $<1 \mathrm{~g} / \mathrm{nap}$, akkor a kezelés intenzitását az extrarenalis manifesztációk határozzák meg $[18,19]$. Akiknél a proteinuria meghaladja a napi 3 g-ot, glükokortikoiddal és calcineurininhi- bitorral kell kezelni. A krónikus veseelégtelenség elkerülése érdekében a szisztolés vérnyomás ajánlott célértéke 110-129 Hgmm [20]. Az ACE-inhibitorok és az ARB-k nemcsak a tenziókontrollban hasznosak, hanem a proteinuriát is csökkentik [21]. A II-es megszünhet, relabálhat vagy progredálhat III-as, IV-es típusba, ekkor az ottani kezelési elvek érvényesek.

\section{ISN III. és IV. osztályú lupus nephritis indukciós kezelése (1. ábra)}

Remisszióindukciós kezelés során a mycofenolat mofetilt (MMF per os napi 2-3 g) vagy cyclophosphamidot alkalmazunk (CYC) glükokortikoiddal kombinálva. Parciális remisszióról akkor beszélünk, ha a kiinduló kóros értékhez képest a becsült glomerulusfiltrációs ráta (eGFR) $25 \%$-kal javult, a proteinuria mértéke 50\%-kal csökkent és a vizeletüledék inaktívvá vált. Teljes a remisszió, ha az eGFR $>90 \mathrm{ml} / \mathrm{min} / 1,73 \mathrm{~m}^{2}, 50 \%$-kal csökkent a vizelet fehérje/kreatinin arány és inaktív a vizeletüledék [22].

A cyclophosphamid adására több protokoll is érvényben van. Adható a NIH (National Institutes of Health, Nemzeti Egészségügyi Intézet) -protokoll alapján 0,75-

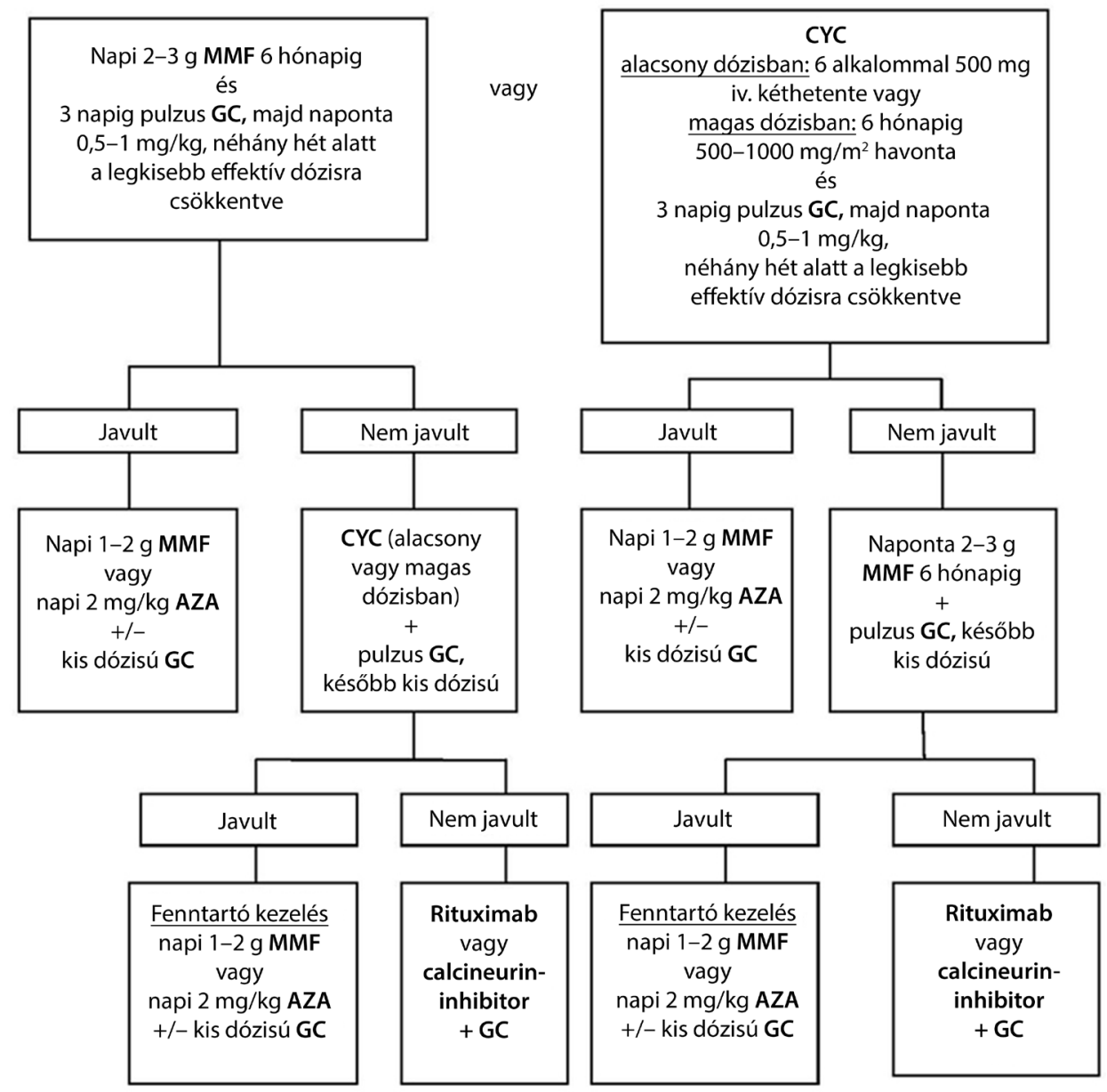

\begin{tabular}{l|l} 
1. ábra & Az indukciós kezelés algoritmusa III-as és IV-es osztályú lupus nephritisben \\
AZA $=$ azathioprin; $C Y C=$ cyclophosphamid; GC $=$ glükokortikoid; $M M F=$ mycofenolat mofetil
\end{tabular} 
$1 \mathrm{~g} / \mathrm{m}^{2}$ dózisban havonta, összesen 6 alkalommal, majd vagy negyedévente a CYC-infúziókat folytatjuk, vagy azathioprin (AZA), illetve MMF fenntartó terápiára térünk át. Később a toxicitás csökkentése érdekében törekedtek az összdózis és a kezelés időtartamának csökkentésére: az EUROLUPUS-protoll alapján kéthetente kell iv. $500 \mathrm{mg}$-ot adni összesen 6 alkalommal, majd szintén AZA vagy MMF fenntartó kezelést folytatunk. Az EUROLUPUS eredményei teljes egészében nem vethetők össze a NIH-vizsgálattal, ugyanis ott több volt az afroamerikai a beválogatott betegek között, akikben ismerten rosszabb a prognózis [23-25].

Az MMF és a CYC tanulmányok, metaanalízisek és szakértői vélemények alapján is egyenlő hatékonyságúak az indukciós terápiában $[26,27]$. Habár MMF-fel lényegesen kevesebb hosszú távú vizsgálat van, mint cyclophosphamiddal, az ALMS vizsgálat (Aspreva Lupus Management Study) adatai alapján 6 hónapig napi 3 g-os indukciós, majd napi 2 g-os fenntartó dózisban hatékony a lupus nephritis kezelésében [28]. A 2 g-os kezdő dózis is elfogadható, ha nincs félhold-képződés és a kreatininszint stabil.

Az MMF aktív metabolitjának, a mikofenolsavnak (MPA) és a mycofenolat nátriumnak a hatékonyságát több, jelenleg folyó klinikai vizsgálat próbálja feltérképezni. $720 \mathrm{mg}$ mycofenolat nátrium felel meg $1 \mathrm{~g}$ MMFnek. Szakértők véleménye alapján ugyanolyan hatékony, mint az MMF, azonban jobb gastrointestinalis tolerálhatósága kérdéses [29, 30].

A glükokortikoidterápia önmagában nem eléggé effektív, kiegészítő terápiaként használjuk a CYC vagy az MMF mellé. Nincs egyértelmú irányelv a szteroid dózisára vonatkozóan, de a legtöbb vizsgálat NIH-protokoll alapján indukciós terápia során iv. 50-1000 mg methylprednisolont ír elő 3 napig, per os folytatva $0,5-1 \mathrm{mg} /$ kg dózisról indulva napi 5-10 mg-ra csökkentve [31].

A tacrolimus alternatív szer lehet, ha a beteg nem tolerálja a standard terápiát. Több vizsgálat alapján a cyclophosphamidnál biztonságosabb és a teljes remisszió elérésében hatékonyabb [32].

A LUNAR (Lupus Nephritis Assessment with Rituximab) nemzetközi vizsgálat 2012-ben az MMF és szteroid mellé adott rituximabot hatékonynak találta, de komplett remisszió elérésének tekintetében nem volt statisztikailag szignifikáns az eredmény [33].

\section{ISN III/IV. osztályú lupus nephritis fenntartó kezelése}

A lupus nephritises betegek közel 50\%-ában alakul ki relapsus, ezért különösen fontos a megfelelö fenntartó terápia. Korábban a NIH-vizsgálat alapján cyclophosphamid volt az elsőként választandó szer erre a célra negyedévenkénti adagolással $\left(0,75-1 \mathrm{~g} / \mathrm{m}^{2}\right)$, ugyanakkor a jelentős mellékhatások (meddőség, alopecia, húgyhólyag-carcinoma, csontvelő-depresszió) miatt ez mára visszaszorult [34].
Ma az azathioprint (naponta 2-2,5 $\mathrm{mg} / \mathrm{kg}$ dózisban) vagy az MMF-et (naponta $2 \mathrm{~g}$ ) alkalmazzuk fenntartó kezelésként. A közelmúltban két prospektív vizsgálat tanulmányozta az LN-es betegek fenntartó terápiáját. $\mathrm{Az}$ Aspreva Lupus Management Studyban (ALMS) a betegeket vagy naponta $2 \mathrm{mg} / \mathrm{kg}$ AZA-ra vagy napi $2 \mathrm{~g}$ MMF-re randomizálták, maximum $10 \mathrm{mg}$ napi glükokortikoid mellett. A hároméves utánkövetés során az MMF statisztikailag szignifikánsan hatékonyabbnak bizonyult, mint az AZA, és mellékhatása is szignifikánsan kevesebb volt. A MAINTAIN nephritisvizsgálatban [35] a betegeket cyclophosphamid indukciós kezelés után szintén napi $2 \mathrm{mg} / \mathrm{kg}$ AZA-ra vagy napi $2 \mathrm{~g}$ MMF-re randomizálták, és 4 év utánkövetéssel nem találtak különbséget a két csoport között.

Az EULAR [36] és az ACR ajánlása alapján mindkét gyógyszer használható LN fenntartó kezelésére. A terhességet tervező betegeknél az MMF teratogenitása miatt csak az AZA jöhet szóba. A calcineurininhibitor (CNI), mint például a tacrolimus, alternatíva lehet azokban az esetekben, ahol a betegek a standard terápiát nem tolerálják. A tacrolimusnak erős antiproteinuriás hatása van és terhesség alatt is szedhető. Ugyanakkor a toxicitásprofilja (magas vérnyomás, kedvezőtlen lipidhatások, tremor, hirsutismus) és a megvonása után jelentkező rebound proteinuria miatt első vonalbeli adása egyelöre megfontolandó.

Kevesen vizsgálták eddig, hogy az immunszuppresszív szerek mikor hagyhatók el [37], a válasz erösen páciensfüggő, de összességében ragaszkodnunk kell a minimum 5 éves gyógyszeres remisszióhoz, ugyanakkor ajánlatos a glükokortikoidok dózisát minél hamarabb lecsökkenteni, különösen akkor, ha nincs a betegnek extrarenalis manifesztációja.

\section{Membranosus lupus nephritis kezelése}

A membranosus lupus glomerulonephritisre (ISN/RPS class V) a subepithelialis immundepozitum jelenléte jellemző. Általában a proliferatív III/IV. osztályú LN-hez társul, ilyenkor a proliferatív forma kezelése a meghatározó. Néhány betegben azonban izoláltan alakul ki, vagy a veseérintettség kezdő tüneteként, vagy később a proliferatív betegség gyógyulása során. A kezelése megegyezik az idiopathiás membranosus nephropathiáéval. A betegek szoros kontrollja és az angiotenzin-renin-aldoszteron rendszer blokkolása elegendő. Ha súlyos proteinuria is jelen van, akkor az immunszuppresszív szerek adása (glükokortikoidok, MMF, AZA vagy $\mathrm{CNI}$ ) nem mellőzhető.

Tisztán membranosus LN-es betegek körében a NIH kontrollált vizsgálatot folytatott: a betegek egyharmada cyclosporin A-t (CsA) és másnaponta glükokortikoidot kapott, harmada kéthavonta cyclophosphamidot és glükokortikoidot, további egyharmada csak másnaponta glükokortikoidot. A CYC és a CsA is egyértelmûen hatékonyabb volt, mint önmagában a szteroid, CsA-val re- 
misszió hamarabb jött létre, de gyakoribbak voltak a relapsusok, mint CYC-cel [38]. Egy másik vizsgálat az MMF és CYC hatékonyságát vetette össze tisztán membranosus $\mathrm{LN}$-es betegekben és a két szert egyformán hatékonynak találta 24 hét alatt [39].

\section{Biológiai terápiák lupus nephritisben}

A rituximab off-label alkalmazása egyre inkább terjed, és a belimumabbal folyó [40] klinikai vizsgálatoknak is van már biztató eredménye.

A belimumab egy monoklonális B-lymphocyta-stimulátor (BlyS) elleni antitest. A BlyS a B-sejtek túlélését, differenciálódását, Ig-szekrécióját és az izotípusváltást segíti, SLE-s betegekben gyakran figyelhető meg a túlprodukciója, gátlása csökkenti a CD20+ B-lymphocyták számát és a plazmasejtek életidejét. Hatékony a fellángolások, a betegségaktivitás és a proteinuria csökkentésében [41].

A rituximab egy kiméra monoklonális CD20 elleni antitest, tanulmányok alapján hatékonynak bizonyult az indukciós és a fenntartó terápiában is. Kiemelt szerepe lehet a refrakter esetek kezelésében [42], emellett kiemelten hatékony a kevert membranosus-proliferatív és a III. osztályú LN kezelésében. A folyamatban levő RING európai, randomizált, kontrollált vizsgálat a rituximab hatékonyságát elemzi refrakter lupus nephritises betegek körében [43].

Az abatacept egy szolúbilis Fc- $\gamma$ :CTLA-4 fúziós fehérje, amely az antigénprezentáló sejtek és T-sejtek közötti CD80/86-CD28 kostimulációs útvonalat gátolva blokkolja a T-sejtek aktiválását. A kezelés során csökken az antigén-prezentáló sejt aktivitása és az általa termelt citokinszint is. Egy abataceptet MMF-fel és glükokortikoiddal együtt adó fázis II/III. vizsgálatot hatástalanság miatt leállítottak [40].

Az ocrelizumab, humanizált anti-CD20 monoklonális antitesttel folytatott vizsgálatot a súlyos fertőzések magas száma miatt leállították.

A tabalumab, Blys elleni monoklonális antitest hatékonyságának vizsgálatára szintén fázis II/III. vizsgálatok folynak.

Az SLE patogenezisében ismert interferonút érintettsége alapján az antiinterferon szerek hatékonyságát is vizsgálják a betegségben, eddig érdemi pozitív eredmények nélkül [41].

\section{A bidroxikloroquin szerepe a lupus nephritis kezelésében}

Az antimaláriás szereket régóta használják az SLE kezelésében, az utóbbi években került előtérbe a szerepük a lupus nephritis kezelésében. A Hopkins lupus kohorsz prospektív adatbázis [44] eredményei alapján membranosus lupus nephritisben MMF-fel kombinálva a hidroxikloroquin (6-6,5 $\mathrm{mg} / \mathrm{kg}$ dózisban) növeli a komplett renalis válasz elérésének esélyét. A hidroxikloroquinnal (HCQ) kezelt betegek 64\%-ában alakult ki egy éven belül remisszió, míg akik nem kaptak HCQ-t, azoknak csak a 22\%-ában [45], emellett a HCQ bizonyítottan véd az LN kialakulása, az LN relapsusa és a végstádiumú veseelégtelenség kialakulása ellen, valamint kedvezően hat a lipidprofilra [46]. Ismert retinatoxicitása miatt a betegek rendszeres szemészeti kontrollja szükséges.

\section{Dializis, veseátültetés}

A lupus nephritises betegek 10-20\%-ánál nem kerülhető el a veseátültetés [45]. Refrakter esetben, ha a vese már nem menthető, megfontolandó az immunszuppresszív terápia csökkentése, hogy az egyéb mellékhatásokat elkerüljük. Érdemes inkább a hemodialízist előnyben részesíteni a retroperitonealis dialízissel szemben az alacsonyabb infekciós ráta miatt [47].

A lupusos végstádiumú veseelégtelen betegek nagy része alkalmas veseátültetésre. Jobbak az eredmények a korai transzplantációval és az élő donoros beültetéssel [48]. $\mathrm{Az}$ LN rekurrálása a graftban előfordulhat, de ritka (1-4\%). Összességében a graft túlélése nem rosszabb, mint az egyéb okból kialakult veseelégtelen betegeknél. Rossz prognosztikai tényezők a cadaver transzplantáció, az antifoszfolipid antitestek jelenléte, a megelőző hoszszas dialízis, rossz általános állapot és a perzisztens lupusaktivitás [49].

\section{Saját tapasztalataink lupus nephritises betegek MMF-kezelésével}

A mycofenolatot (2. ábra) elsőként szervtranszplantáltaknál alkalmazták a rejekció megelőzésére, majd használata a szisztémás autoimmun betegségekben is terjedni kezdett [50]. Reverzibilisen gátolja az inozin-monofoszfát-dehidrogenázt, így a guanin nukleotidképződését, ezáltal csökkenti a B- és a T-lympocyta-proliferációt. Leggyakoribb mellékhatásai a hányinger, hányás, hasmenés, láz, fejfájás, kiütés, hátfájás, tremor, leukopenia, malignitás, pancreatitis [35]. Az amenorrhoea, leukopenia, alopecia tekintetében cyclophosphamidnál kedvezőbb mellékhatásprofilja indokolja terjedését a lupus nephritis kezelésében [34].

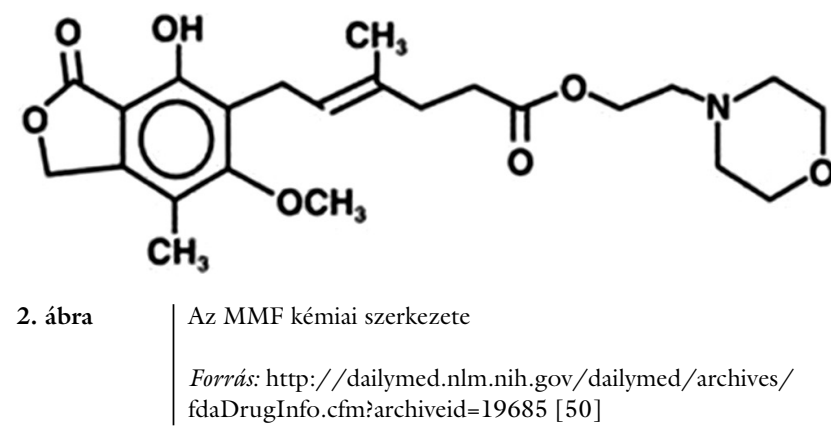


Demográfiai adatok $(\mathrm{n}=25$

Kor, év az SLE diagnózis felállításakor; átlag

$29,75(14-60)$ (minimum-maximum)

Kor, év az LN diagnózisakor; átlag (minimum$31,99(21-60)$ maximum)

LN megjelenéséig eltelt évek száma; átlag (minimum-maximum)

$5,92(0-13)$

Nők, n (\%)

$21(84 \%)$

$\mathrm{LN}=$ lupus nephritis; MMF = mycofenolat mofetil; SLE = szisztémás lupus erythematosus.

3. táblázat $\mid$ Lupus nephritises betegeink szövettani típus szerinti megoszlása

\begin{tabular}{ll}
\hline Szövettani beosztás $(\mathrm{n}=24)$ & \\
\hline Class I, n $(\%)$ & $0(0 \%)$ \\
\hline Class II, n $(\%)$ & $1(4,16 \%)$ \\
\hline Class III $(\mathrm{A}), \mathrm{n}(\%)$ & $3(12,5 \%)$ \\
\hline III $(\mathrm{A} / \mathrm{C}), \mathrm{n}(\%)$ & $7(29,1 \%)$ \\
\hline III $(\mathrm{C}), \mathrm{n}(\%)$ & $0(0 \%)$ \\
\hline Class IV: diffúz szegmentális (IV-S) vagy globális & $1(4,16 \%)$ \\
\hline IV-G) & $7(29,1 \%)$ \\
\hline IV $(\mathrm{A}), \mathrm{n}(\%)$ & $3(12,5 \%)$ \\
\hline IV $(\mathrm{A} / \mathrm{C}), \mathrm{n}(\%)$ & $1(4,16 \%)$ \\
\hline IV $(\mathrm{C}), \mathrm{n}(\%)$ & $1(4,16 \%)$ \\
\hline Class V & $0(0 \%)$ \\
\hline Class VI &
\end{tabular}

4. táblázat | A kémiai markerek változásának összefoglalása féléves MMF-kezelés után

Kémiai markerek, átlagosan féléves MMF-adás után

Karbamid (mmol/l)

Előtte; átlag (minimum-maximum); $\mathrm{n}=10 \quad 8,4(7,2-10,7)$

Utána; átlag (minimum-maximum); $\mathrm{n}=10 \quad 4,8(3,2-12,6)$

Kreatinin ( $\mu \mathrm{mol} / \mathrm{l})$

Előtte; átlag (minimum-maximum); $\mathrm{n}=7 \quad 175$ (79-379)

Utána; átlag (minimum-maximum); $\mathrm{n}=7 \quad 54,68$ (28-66)

GFR

GFR előtte; átlag (minimum-maximum); n =6 54,6 (42-112)

GFR utána; átlag (minimum-maximum); n = $6 \quad 69$ (61-93)

Vizeletüledék (aktiv - vvs., Hg, granularis vagy tubularis sejtes elemek)

\begin{tabular}{ll}
\hline Aktív elötte; n (\%) & $9(36 \%)$ \\
\hline Aktív utána; n (\%) & $3(12 \%)$ \\
\hline Proteinuria (g/nap) & $3,18(0,8-7,24)$ \\
\hline Elötte; átlag (minimum-maximum) & $1,06(0,23-2,14)$ \\
\hline Utána; átlag (minimum-maximum) &
\end{tabular}

GFR = glomerulusfiltrációs ráta MMF = mycofenolat mofetil.
Intézetünkben 31 betegnek kértünk egyedi méltányossággal támogatást mycofenolat mofetil adásához. Közülük 25 beteg lupus nephritis, hárman SLE egyéb manifesztációi, egy polychondritis és egy retroperitonealis fibrosis diagnózissal kapta a szert, adataikat retrospektíven elemeztük.

A lupus nephritises betegek átlagéletkora 29,75 év volt az SLE diagnózisának felállításakor és 31,99 év az LN kialakulásakor. 52\%-uknak már az SLE diagnózisának felállításakor nephritise volt, ez a nemzetközi irodalmi adatoknak megfelel, a betegek további $48 \%$-ában az LN megjelenéséig átlagosan mintegy 6 év telt el. Jelentős női dominancia volt megfigyelhető $(84 \%)$ (2. táblázat).

Betegeink többsége III (A/C) fokális $(30 \%)$ vagy IV (A) diffúz (30\%) glomerulonephritis szövettani csoportba tartozott (3. táblázat).

Féléves MMF-kezelés után a betegek vesefunkciója javult: szérumkarbamidszintjük átlag $8,4 \mathrm{mmol} / \mathrm{l}$-ről 4,8 mmol/l-re, kreatininszintjük átlag $175 \mu \mathrm{mol} / \mathrm{l}$-ről 54,68 $\mu \mathrm{mol} / 1$-re csökkent, a GFR 54,6 ml/min/1,73 $\mathrm{m}^{2}$-ről 69 -re nôtt, a vizeletüledék $60 \%$-uknál inaktívvá vált, a napi vizeletfehérje-ürítés 3,18 g-ról 1,06 g-ra csökkent (4. táblázat).

Minden beteg glükokortikoidkezelésben részesült a mycofenolat megkezdésekor. Egy betegnél alkalmaztuk primeren remisszióindukcióra az MMF-et, a többiek a cyclophoshamid hatástalansága miatt vagy cyclophosphamiddal elért remisszió fenntartására kapták. A betegek $68 \%$-a azathioprint, 36\%-a cyclosporint, $20 \%$-a kloroquint, $8 \%$-a methotrexatot szedett korábban az SLE valamely manifesztációjának kezelésére. Rituximabot 12\%-uk, IVIG-et (intravénás immunglobulin) 8\%-uk kapott (5. táblázat).

A betegek $48 \%$-ában parciális, $24 \%$-ában komplett remissziót tudtunk elérni vagy fenntartani, két betegnél következett be relapsus, egy beteg gastrointestinalis mel-

\section{5. táblázat $\mid$ Mycofenolatkezelést megelőzően adott terápiák}

\begin{tabular}{ll}
\hline Korábbi terápia, $\mathrm{n}=25$ & \\
\hline Glükokortikoid, $\mathrm{n}(\%)$ & $25(100 \%)$ \\
\hline Cyclophosphamid, $\mathrm{n}(\%)$ & $24(96 \%)$ \\
\hline Azathioprin, $\mathrm{n}(\%)$ & $17(68 \%)$ \\
\hline Cyclosporin, $\mathrm{n}(\%)$ & $9(36 \%)$ \\
\hline Kloroquin, $\mathrm{n}(\%)$ & $5(20 \%)$ \\
\hline Rituximab, $\mathrm{n}(\%)$ & $3(12 \%)$ \\
\hline IVIG, $\mathrm{n}(\%)$ & $2(8 \%)$ \\
\hline Methotrexat, $\mathrm{n}(\%)$ & $2(8 \%)$ \\
\hline Tacrolimus, $\mathrm{n}(\%)$ & $1(4 \%)$ \\
\hline Talidomid, $\mathrm{n}(\%)$ & $1(4 \%)$ \\
\hline Sulfasalazin, $\mathrm{n}(\%)$ & $1(4 \%)$ \\
\hline Leflunomid, $\mathrm{n}(\%)$ & $1(4 \%)$ \\
\hline
\end{tabular}


lékhatások, egy pedig tervezett gyermekvállalás miatt hagyta el a gyógyszert. Egy betegnél kellett hatástalanság miatt másik szerre váltani, és egy beteg exitált (6. táblázat). A komplett és parciális remissziót elért csoport között nem volt szignifikáns különbség a betegek SLE diagnózis felállításkori életkorát tekintve (a komplett remissziót elértek között 28 év volt az átlagéletkor, a parciális választ adók között 28,5 év). A komplett remissziót mutató csoportban az SLE diagnózisa után korábban jelentkezett az LN (átlagosan 1,8, illetve 2,18 év), valamint a komplett remissziót elértek között nagyobb volt a Class IV GN aránya (67, illetve $57 \%)$. Náluk a betegek 30\%-ában szekunder antifoszfolipid-szindróma társult, de egyéb autoimmun betegség nem volt jelen. A parciális választ adók között az autoimmun betegség társulása ugyanilyen arányban fordult elő, két betegnél Raynaudszindróma, egy betegnél epidermolysis bullosa aquisita, egy betegnél pedig fokális myositis volt jelen.

6. táblázat |A mycofenolatkezelés kimenetele

\begin{tabular}{lc}
\hline MMF-kezelés kimenetele $(\mathrm{n}=24)$ & $12(48 \%)$ \\
\hline Parciális remisszió, $\mathrm{n}(\%)$ & $6(24 \%)$ \\
\hline Komplett remisszió, $\mathrm{n}(\%)$ & $2(8 \%)$ \\
\hline Relapsus, $\mathrm{n}(\%)$ & $1(4 \%)$ \\
\hline Gastrointestinalis mellékhatás miatt elhagyta, $\mathrm{n}(\%)$ & $1(4 \%)$ \\
\hline Tervezett terhesség miatt elhagyta, $\mathrm{n}(\%)$ & $1(4 \%)$ \\
\hline Exitus, $\mathrm{n}(\%)$ & $1(4 \%)$ \\
\hline Hatástalanság, $\mathrm{n}(\%)$ &
\end{tabular}

\section{Következtetések}

Az immunszuppresszív terápia fejlődésével az elmúlt évtizedekben a lupus nephritises betegek életkilátása jelentősen javult. Napjainkra a III-as és IV-es típusú lupus nephritis kezelésében már az indukció során is a cyclophosphamid alternatívájává vált a kedvezőbb mellékhatásprofilú MMF. Sajnálatos módon hazánkban egyelőre egyedi hatósági méltányossági engedélyhez kötött a mycofenolat támogatása, amelynek támogatás nélküli havi költsége meghaladja az 50 ezer forintot. Az engedélyeztetés időigényessége miatt akut LN-ben a gyors elérhetőség miatt betegeink többségénél cyclophosphamidterápiát kezdtünk, majd fenntartó kezelésként váltottunk MMF-re. Egy betegünk gyógyszervizsgálat keretén belül indukciós terápiaként kapta az MMF-et. Tapasztalatunk szerint az MMF hatékony volt a remisszió fenntartásában, fél év alatt jelentősen javította a vesefunkciót és csökkentette a proteinuriát. Alkalmazásával elkerülhető a cyclophosphamid adásához szükséges hospitalizáció, így összességében kisebb terhet ró a társadalombiztosításra, mint a cyclophosphamidterápia. További előnye, hogy nem okoz korai petefészek-kimerülést, bár kétségtelen, hogy teratogén hatása miatt megfelelő fogamzásgátlásról kell gondoskodni. Itt azonban figyelembe kell venni, hogy aktív lupus nephritis mellett terhesség vállalása egyébként is kontraindikált.

Végezetül kiemelnénk, hogy a beteg gondozása során a túlélés szempontjából kulcsfontosságú a rizikófaktorok kontrollja, így a proteinuria csökkentése és a tenzió normálértéken tartása. Figyelembe kell venni az atherosclerosis és az osteoporosis fokozott rizikóját. A kezelést a beteg klinikai állapotának, szövettani eredményének, egyéni preferenciáinak és a hosszú távú céloknak a figyelembevételével kell meghatározni.

Anyagi támogatás: A közlemény megírása anyagi támogatásban nem részesült.

Szerzői munkamegosztás: Sz. M. Zs.: A közlemény megírása, adatok gyújtése, feldolgozása. K. E.: A kézirat szakmai véleményezése, klinikai adatok szolgáltatása. A kézirat végleges változatát mindkét szerző elolvasta és jóváhagyta.

Érdekeltségek: A szerzőknek nincsenek érdekeltségeik.

\section{Irodalom}

[1] Maroz, N., Segal, M. S.: Lupus nephritis and end-stage kidney disease. Am. J. Med. Sci., 2013, 346(4), 319-323.

[2] Hsu, C. Ү., Chiu, W. C., Yang, T. S., et al.: Age- and gender-related long-term renal outcome in patients with lupus nephritis. Lupus, 2011, 20(11), 1135-1141.

[3] Ippolito, A., Petri, M.: An update on mortality in systemic lupus erythematosus. Clin. Exp. Rheumatol., 2008, 26(5 Suppl. 51), S72-S79.

[4] Imran, T. F., Yick, F., Verma, S., et al.: Lupus nephritis: an update. Clin. Exp. Nephrol., 2016, 20(1), 1-13.

[5] Austin, H. A. 3rd, Muenz, L. R., Joyce, K. M., et al.: Prognostic factors in lupus nephritis. Contribution of renal histologic data. Am. J. Med., 1983, 75(3), 382-391.

[6] Cooper, G. S., Dooley, M. A., Treadwell, E. L., et al.: Risk factors for development of systemic lupus erythematosus: allergies, infections, and family history. J. Clin. Epidemiol., 2002, 55(10), 982-989.

[7] Boackle, S. A.: Advances in lupus genetics. Curr. Opin. Rheumatol., 2013, 25(5), 561-568.

[8] Kiss, E.: Lupus nephritis. In: Kakuk, G. (ed.): Clinical nephrology. [Lupus nephritis. In: Kakuk, G. (szerk.): Klinikai nephrologia.] Medicina Könyvkiadó, Budapest, 2004. [Hungarian]

[9] Blanco, P., Ueno, H., Schmitt, N.: T follicular helper (Tfh) cells in lupus: Activation and involvement in SLE pathogenesis. Eur. J. Immunol., 2016, 46(2), 281-290.

[10] Weening, J. J., D'Agati, V. D., Schwartz, M. M., et al.: The classification of glomerulonephritis in systemic lupus erythematosus revisited. J. Am. Soc. Nephrol., 2004, 15(2), 241-250.

[11] Balow, J. E.: Clinical presentation and monitoring of lupus nephritis. Lupus, 2005, 14(1), 25-30.

[12] Gonzalez-Crespo, M. R., Lopez-Fernandez, J. I., Usera, G., et al.: Outcome of silent nephritis. Semin. Arthritis Rheum., 1996, 26(1), 468-476.

[13] Wakasugi, D., Gono, T., Kawaguchi, r., et al.: Frequency of class III and IV nephritis in systemic lupus erythematosus without clinical renal involvement: an analysis of predictive measures. J. Rheumatol., 2012, 39(1), 79-85.

[14] Moroni, G., Quaglini, S., Gravellone, L., et al.: Membranous nephropathy in systemic lupus erythematosus: long-term outcome 
and prognostic factors of 103 patients. Semin. Arthritis Rheum., 2012, 41(5), 642-651.

[15] Pasquali, S., Banfi, G., Zucchelli, A., et al.: Lupus membranous nephropathy: long term outcome. Clin. Nephrol., 1993, 39(4), 175-182.

[16] Chan, T. M.: Preventing renal failure in patients with severe lupus nephritis. Kidney Int. Suppl., 2005, 67, S116-S119.

[17] Houssiau, F. A., Vasconcelos, C., D'Cruz, D., et al.: Early response to immunosuppressive therapy predicts good renal outcome in lupus nephritis: lessons from long-term followup of patients in the Euro-Lupus Nephritis Trial. Arthritis Rheum., 2004, 50(12), 3934-3940.

[18] Hahn, B. H., McMahon, M. A., Wilkinson, A., et al.: American College of Rheumatology guidelines for screening, treatment and management of lupus nephritis. Arthritis Care Res., 2012, 64(6), 797-808.

[19] KDIGO Clinical Practice Guideline for Glomerulonephritis. Kidney Int. Suppl., 2012, 2(2), 139-274.

[20] Jafar, T. H., Stark, P. C., Schmid, C. H., et al.: Progression of chronic kidney disease: the role of blood pressure control, proteinuria, and angiotensin-converting enzyme inhibition: a patient-level meta-analysis. Ann. Intern. Med., 2003, 139(4), 244252.

[21] Durán-Barragán, S., McGwin, G. Jr., Vilá, L. M., et al.: Angiotensin-converting enzyme inhibitors delay the occurrence of renal involvement and are associated with a decreased risk of disease activity in patients with systemic lupus erythematosus - results from LUMINA (LIX): a multiethnic US cohort. Rheumatology (Oxford), 2008, 47(7), 1093-1096.

[22] The American College of Rheumatology response criteria for proliferative and membranous renal disease in systemic lupus erythematosus clinical trials. Arthritis Rheum., 2006, 54(2), 421432 .

[23] Contreras, G., Pardo, V., Leclercq, B., et al.: Sequential therapies for proliferative lupus nephritis. N. Engl. J. Med., 2004, 350(10), 971-980.

[24] Houssiau, F. A., Vasconcelos, C., D’Cruz, D., et al.: Immunosupressive therapy in lupus nephritis: the Euro-Lupus Nephritis Trial, a randomized trial of low-dose versus high-dose intravenous cyclophosphamide. Arthritis Rheum., 2002, 46(8), $2121-$ 2131.

[25] Houssiau, F. A., Vasconcelos, C., D'Cruz, D., et al.: The 10-year follow-up data of the Euro-Lupus Nephritis Trial comparing low-dose and high-dose intravenous cyclophosphamide. Ann. Rheum. Dis., 2010, 69(1), 61-64.

[26] Chan, T. M., Tse, K. C., Tang, C. S., et al.: Long-term study of mycophenolate mofetil as continuous induction and maintenance treatment for diffuse proliferative lupus nephritis. J. Am. Soc. Nephrol., 2005, 16(4), 1076-1084.

[27] Touma, Z., Gladman, D. D., Urowitz, M. B., et al.: Mycophenolate mofetil for induction treatment of lupus nephritis: a systematic review and metaanalysis. J. Rheumatol., 2011, 38(1), 69-78.

[28] Ginzler, E. M., Appel, G. B., Dooley, M. A., et al.: Aspreva Lupus Management Study (ALMS) maintenance results. [Abstract.] Arthritis Rheum., 2010, 62(Suppl. 10), 2085.

[29] Budde, K., Glander, P., Diekmann, F., et al.: Review of the immunosuppressant enteric-coated mycophenolate sodium. Expert Opin. Pharmacother., 2004, 5(6), 1333-1345.

[30] Budde, K., Dürr, M., Liefeldt, L., et al.: Enteric-coated mycophenolate sodium. Expert Opin. Drug Saf., 2010, 9(6), 981-994.

[31] Boumpas, D. T., Austin, H. A. 3rd, Vaughn, E. M., et al.: Controlled trial of pulse methylprednisolone versus two regimens of pulse cyclophosphamide in severe lupus nephritis. Lancet, 1992, 340(8822), 741-745.

[32] Deng, J., Huo, D., Wu, Q., et al.: A meta-analysis of randomized controlled trials comparing tacrolimus with intravenous cyclophosphamide in the induction treatment for lupus nephritis. Tohoku J. Exp. Med., 2012, 227(4), 281-288.
[33] Rovin, B. H., Furie, R., Latinis, K., et al.: Efficacy and safety of rituximab in patients with active proliferative lupus nephritis: the lupus nephritis assessment with rituximab study. Arthritis Rheum., 2012, 64(4), 1215-1226.

[34] Boumpas, D. T., Austin, H. A. 3rd, Vaughan, E. M., et al.: Risk for sustained amenorrhea in patients with systemic lupus erythematosus receiving intermittent pulse cyclophosphamide therapy. Ann. Intern. Med., 1993, 119(5), 366-369.

[35] Houssian, F. A., D’Cruz, D., Sangle, S., et al.: Azathioprine versus mycophenolate mofetil for long-term immunosuppression in lupus nephritis: results from the MAINTAIN Nephritis Trial. Ann. Rheum. Dis., 2010, 69(12), 2083-2089.

[36] Bertsias, G. K., Tektonidou, M., Amoura, Z., et al.: Joint European League Against Rheumatism and European Renal Association-European Dialysis and Transplant Association (EULAR/ ERA-EDTA) recommendations for the management of adult and paediatric lupus nephritis. Ann. Rheum. Dis., 2012, 71(11), 1771-1782.

[37] Moroni, G., Gallelli, B., Quaglini, S., et al.: With drawal of therapy in patients with proliferative lupus nephritis: long-term follow-up. Nephrol. Dial. Transplant., 2006, 21(6), 1541-1548.

[38] Austin, H. A. 3rd, Illei, G. G., Braun, M. J., et al.: Randomized, controlled trial of prednisone, cyclophosphamide, and cyclosporine in lupus membranous nephropathy. J. Am. Soc. Nephrol., 2009, 20(4), 901-911.

[39] Radhakrishnan, J., Moutzouris, D. A., Ginzler, E. M., et al.: Mycophenolate mofetil and intravenous cyclophosphamide are similar as induction therapy for class $\mathrm{V}$ lupus nephritis. Kidney Int., $2010,77(2), 152-160$.

[40] Van Vollenhoven, R. F., Parodis, I., Levitsky, A.: Biologics in SLE: towards new aproaches. Best Pract. Res. Clin. Rheumatol., 2013, 27(3), 341-349.

[41] Gatto, M., Kiss, E., Naparstek, Ү., et al.: In-/off-label use of biologic therapy in systemic lupus erythematosus. BMC Med., 2014, 12, 30 .

[42] Borchers, A. T., Leibushor, N., Naguwa, S. M., et al.: Lupus nephritis: a critical review. Autoimmun. Rev., 2012, 12(2), 174194.

[43] Houssiau, F. A., Lawwerys, B. R.: Current management of lupus nephritis. Best Pract. Res. Clin. Rheumatol., 2013, 27(3), 319328.

[44] Fangtham, M., Petri, M.: 2013 update: Hopkins lupus cohort. Curr. Rheumatol. Rep., 2013, 15(9), 360.

[45] Fessler, B. J., Alarcón, G. S., McGwin, G. Jr., et al.: Systemic lupus erythematosus in three ethnic groups: XVI. Association of hydroxychloroquine use with reduced risk of damage accrual. Arthritis Rheum., 2005, 52(5), 1473-1480.

[46] Ruiz-Irastorza, G., Ramos-Casals, M., Brito-Zeron, P., et al.: Clinical efficacy and side effects of antimalarials in systemic lupus erythematosus: a systematic review. Ann. Rheum. Dis., 2010, 69(1), 20-28.

[47] Szántó, S., Kiss, E., Szegedi, Gy.: Lupus nephritis and kidney transplantation. [A lupus nephritis és a vesetranszplantáció.] Allergol. Klin. Immunol., 1999, 2(1), 11-15. [Hungarian]

[48] Ward, M. M.: Outcomes of renal transplantation among patients with end-stage renal disease caused by lupus nephritis. Kidney Int., 2000, 57(5), 2136-2143.

[49] Moroni, G., Tantardini, F., Gallelli, B., et al.: The long-term prognosis of renal transplantation in patients with lupus nephritis. Am. J. Kidney Dis., 2005, 45(5), 903-911.

[50] http://dailymed.nlm.nih.gov/dailymed/archives/fdaDrug Info.cfm?archiveid $=19685$

(Szabó Melinda Zsuzsanna dr., Budapest, Frankel Leó út 38-40., 1023 e-mail: szabo.melinda@orfi.hu) 